\title{
Quantifying the deep convective temperature signal within the tropical tropopause layer (TTL)
}

\author{
L. C. Paulik and T. Birner \\ Department of Atmospheric Science, Colorado State University, Fort Collins, CO, USA
}

Correspondence to: T. Birner (thomas@atmos.colostate.edu)

Received: 21 June 2012 - Published in Atmos. Chem. Phys. Discuss.: 7 August 2012

Revised: 12 December 2012 - Accepted: 18 December 2012 - Published: 21 December 2012

\begin{abstract}
Dynamics on a vast range of spatial and temporal scales, from individual convective plumes to planetary-scale circulations, play a role in driving the temperature variability in the tropical tropopause layer (TTL). Here, we aim to better quantify the deep convective temperature signal within the TTL using multiple datasets. First, we investigate the link between ozone and temperature in the TTL using the Southern Hemisphere Additional Ozonesondes (SHADOZ) dataset. Low ozone concentrations in the TTL are indicative of deep convective transport from the boundary layer. We confirm the usefulness of ozone as an indicator of deep convection by identifying a typical temperature signal associated with reduced ozone events: an anomalously warm mid to upper troposphere and an anomalously cold upper TTL. We quantify these temperature signals using two diagnostics: (1) the "ozone minimum" diagnostic, which has been used in previous studies and identifies the upper tropospheric minimum ozone concentration as a proxy for the level of main convective outflow; and (2) the "ozone mixing height", which we introduce in order to identify the maximum altitude in a vertical ozone profile up to which reduced ozone concentrations, typical of transport from the boundary layer are observed. Results indicate that the ozone mixing height diagnostic better separates profiles with convective influence than the ozone minimum diagnostic. Next, we collocate deep convective clouds identified by CloudSat 2B-CLDCLASS with temperature profiles based on Constellation Observing System for Meteorology, Ionosphere, and Climate (COSMIC) Global Position System (GPS) radio occultations. We find a robust large-scale deep convective TTL temperature signal, that is persistent in time. However, it is only the convective events that penetrate into the upper half of the TTL that have a significant impact on TTL temperature. A distinct
\end{abstract}

seasonal difference in the spatial scale and the persistence of the temperature signal is identified. Deep-convective cloud top heights are on average found to be well described by the level of neutral buoyancy.

\section{Background}

The interface between the troposphere and the stratosphere is best described as a transition layer. In the tropics, this region is known as the tropical tropopause layer (TTL). The TTL extends from the level of main convective outflow $\sim 200 \mathrm{hPa}$ to the lower stratosphere $\sim 70 \mathrm{hPa}$, and is unique in that it shares both tropospheric and stratospheric characteristics. For example, ozone increases rapidly with height above the level of main convective outflow, whereas temperature continues to decrease up to the cold point tropopause (CPT) $\sim 100 \mathrm{hPa}$ (Fueglistaler et al., 2009, and references therein). Importance is placed upon this region because it sets the boundary condition for atmospheric tracers entering the stratosphere. Specifically, TTL temperatures control stratospheric water vapor concentrations, which dictate the radiative budget of the stratosphere. Brewer (1949) proposed the "freeze-drying" mechanism in order to explain the very low water vapor concentrations measured throughout the stratosphere: tropospheric air ascending into the stratosphere through the cold tropical tropopause dehydrates to the saturation mixing ratio corresponding to the coldest point along the trajectory. The notion of the Lagrangian cold point determining stratospheric water vapor, which takes into account both horizontal and vertical transport through the TTL is consistent with this picture (e.g. Holton and Gettelman, 2001; Fueglistaler et al., 2005). Because stratospheric water vapor

Published by Copernicus Publications on behalf of the European Geosciences Union. 
concentrations are linked to TTL temperatures and their variability, e.g. clearly seen in the so-called tape recorder signal (Mote et al., 1996), a deep understanding of TTL temperature is desirable. However, the region is complex given that a vast range of spatial and temporal scales affect TTL temperature, and its location makes it susceptible to both stratospheric and tropospheric influence.

While, from above, the global-scale stratospheric circulation significantly influences the temperature and composition of the TTL, tropical deep convection, from below, has the capacity to transport air from the boundary layer to TTL altitudes on the timescale of $1-2 \mathrm{~h}$ and create significant temperature anomalies within the TTL. Previous studies have found ozone to be a useful indicator of deep convection, where low ozone concentrations in the TTL are indicative of deep convective transport from the boundary layer (Kley et al., 1996; Folkins et al., 1999). In turn, this transport alters the region's radiative budget. Steady convective influence maintains the lapse rate in the upper troposphere near the moist adiabatic lapse rate (Folkins and Martin, 2005); however, increasing stratospheric control causes the lapse rate to decrease. The point where the lapse rate starts to deviate from the moist adiabat defines the lapse rate maximum $(\mathrm{LRM})^{1}$. While deep convection can penetrate past the LRM, this level gives an indication of where direct convective control becomes less dominant (Gettelman and Forster, 2002). The LRM tends to occur at a higher altitude in regions with a high frequency of deep convection, resulting in a typical longitudinal structure with higher LRM over the west Pacific and Africa (Gettelman and Birner, 2007).

The lapse rate changes arise from temperature anomalies created by deep convection. Randel and Wu (2003) and Gettelman and Birner (2007) successfully revealed the regional convective temperature signal when looking at temperature departures from the January zonal mean. The signal is characterized by an anomalously warm upper troposphere up to $150 \mathrm{hPa}$ and an anomalously cold TTL with the coldest temperatures at the CPT. Mid to upper tropospheric warming represents the direct response to deep convective latent heating. Cooling at TTL levels, as first revealed in radiosonde data by Johnson and Kriete (1982), represents an indirect response to the warming. Holloway and Neelin (2007) described the cooling, resulting in what they term the "convective cold top", as a natural response to the deep convective heating. Their results from a simple hydrostatic model indicated the cooling is the result of horizontal pressure gradients that extend above the heating leading to divergence aloft. Rising motion occurs in order to conserve mass, and this rising motion causes adiabatic cooling. Norton (2006) described a zonal mean TTL level cold anomaly

\footnotetext{
${ }^{1}$ Note, the LRM has been used in some past studies to refer to the minimum of the potential temperature gradient. Here, we adopt the more straightforward definition based on the conventionally defined lapse rate as the rate of decrease of temperature with height $\left(-\frac{\partial T}{\partial z}\right)$.
}

as a wave response to tropospheric diabatic heating, signifying the presence of a zonal-mean wave-driven circulation generated by equatorial Rossby waves (i.e. different from the stratospheric meridional circulation which is driven by extratropical waves). Furthermore, a cold anomaly near the tropopause is a common feature associated with convectively coupled equatorial waves (e.g. Randel and Wu, 2003; Sherwood et al., 2003; Kiladis et al., 2009), the Madden-Julian Oscillation (e.g. Kiladis et al., 2001, 2005; Ma and Kuang, 2011; Zeng et al., 2012), and the warm phase of the El Niño Southern Oscillation (ENSO) (e.g. Kiladis et al., 2001; Randel and Thompson, 2011). Kim and Son (2012) find the intraseasonal variability of the temperature of the CPT to be dominated by Kelvin wave activity and the MJO.

Sherwood and Wahrlich (1999) and Sherwood et al. (2003) studied the deep convective temperature signal at tropical radiosonde stations associated with low satellite brightness temperatures. Their constructed deep convective life cycle is marked by cooling in the lower to mid troposphere, warming in the mid to upper troposphere, and cooling at TTL altitudes. More recently, Folkins et al. (2008) and Mitovski et al. (2010) successfully revealed similar local convective temperature signals associated with high rainfall rates from the Tropical Rainfall Measuring Mission (TRMM) at tropical radiosonde stations. These earlier studies were limited by (1) using proxies for deep convective clouds (brightness temperature, rain rate), (2) the limited spatial coverage given by the small number of radiosonde station locations. More direct measurements of deep convective cloud tops as well as temperature measurements spanning the entire tropics are required in order to achieve a more complete sense of the structure, scale, and lifetime of the deep convective temperature signal in the TTL and its associated consequences for dehydration. This study combines the use of recent datasets with unprecedented coverage and resolution for characterization of deep convective impact on TTL temperatures.

This paper will proceed by describing the data and prescribed methods in Sect. 2. Section 3 presents results from the Southern Hemisphere Additional Ozonesondes (SHADOZ) dataset, where ozone is used to identify the deep convective temperature signal. Section 4 presents results based on satellite data from the CloudSat and Constellation Observing System for Meteorology, Ionosphere, and Climate (COSMIC) missions that describe the structure, scale, and lifetime of the convective temperature signal. Finally, Sect. 5 combines the use of SHADOZ and CloudSat data in a discussion of deep convective influence on TTL properties.

\section{Data and methods}

Quantifying the deep convective temperature signal within the TTL strongly benefits from the use of multiple datasets. Here, we describe the datasets utilized in this study and 


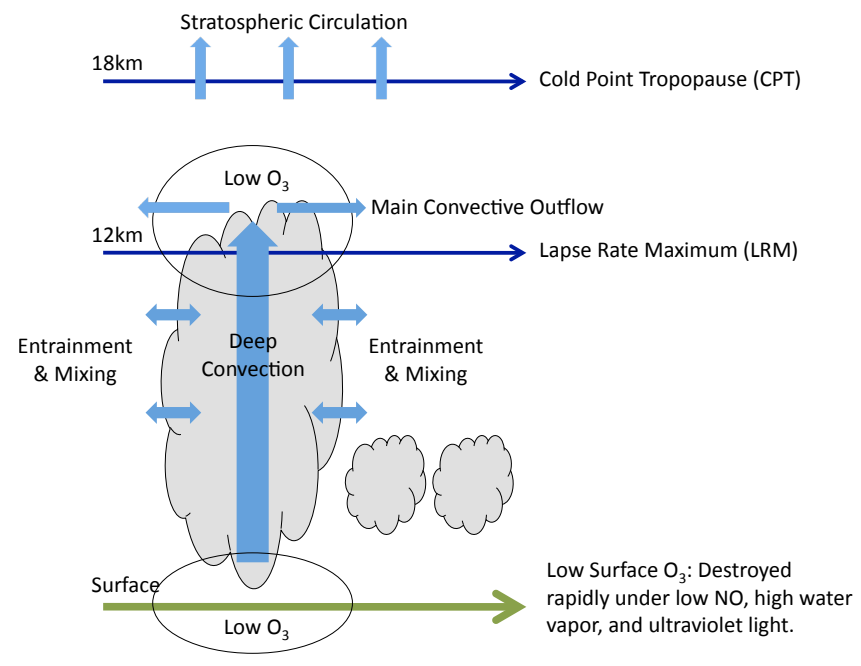

Fig. 1. A conceptual model for understanding ozone as a tracer of deep convection. Low ozone concentrations near the surface can be transported to the upper troposphere within deep convective updrafts and detrained around the level of deep convective outflow. Entrainment and mixing can dilute the updraft, distorting the convective ozone signal.

motivate why observing the TTL in this way is useful. First, we use tropospheric ozone measurements to gain insight into the deep convective temperature signal. Low ozone concentrations in the upper troposphere, referred to as reduced ozone events, indicate deep convective transport from the boundary layer (Kley et al., 1996; Folkins et al., 1999, 2002). Figure 1 provides a schematic for understanding ozone as an indicator of deep convection. The marine boundary layer maintains low ozone concentrations ( $\sim 20$ part per billion by volume, ppbv) due to chemical ozone destruction in the presence of sufficient sunlight, high water vapor, and low nitric oxide (NO) concentrations. While ozone concentrations typically increase from the surface up to the tropopause, low ozone concentrations at the surface may be transported to the upper troposphere within deep convective plumes and detrained at the level of convective outflow. Hence, anomalously low ozone concentrations in the upper troposphere can diagnose a recent convective event. Entrainment mixes environmental air into the convective updraft diluting the plume, yet ozone still proves to be an effective tracer for diagnosing deep convection (Folkins et al., 2002).

Beginning in 1998, the Southern Hemisphere Additional Ozonesondes (SHADOZ) data set provides consistent ozone soundings in regions lacking data (Thompson et al., 2003a,b). Balloon-borne electrochemical concentration cell (ECC) ozonesondes measure ozone via a reaction with potassium iodide (Komhyr et al., 1995). Ozonesondes are flown with standard radiosondes to concurrently obtain vertical profiles of standard meteorological variables (such as temperature and pressure). We have examined data from 1998-2009 at ten SHADOZ stations located throughout the tropics but will focus here on Pago Pago, American Samoa $\left(14.23^{\circ} \mathrm{S}, 170.56^{\circ} \mathrm{W}\right)$. This station is of particular interest for looking at ozone as an indicator of deep convection because it has a pristine marine environment and is located in the west Pacific where there is a high occurrence rate of deep convection (Fig. 2). While reduced ozone events are not a direct observation of a deep convective plume, here they are used as proxy to better understand the deep convective temperature signal. We will concentrate on American Samoa in the results section and remark on differences and similarities to results from other SHADOZ stations in the discussion section. A more complete account of the results at the other stations is given in Paulik (2011).

CloudSat 2B-CLDCLASS offers direct observation of clouds associated with deep convective events. The CloudSat mission, launched in June 2006, provides vertical distributions of hydrometeors at $240 \mathrm{~m}$ vertical resolution using a 94GHz Cloud Profiling Radar (Stephens et al., 2002). CloudSat has a sun-synchronous orbital period of $99 \mathrm{~min}$ with overpasses at 01:30 a.m./p.m. LT, i.e. it crosses the equator about 14 times per day and crosses the same location roughly every 11 days. The CloudSat data product, 2B-CLDCLASS, identifies eight cloud types by means of radar reflectivity (Sassen and Wang, 2008). With this algorithm, we can determine cloud penetration into the TTL by locating deep convective cloud top pixels. We accomplish this by sorting each 2BCLDCLASS granule, identifying pixel columns that contain deep convective clouds. If a column is flagged as containing a deep convective cloud, the height, location, and time of the maximum deep convective cloud pixel is recorded. A record of deep convective cloud tops pixels between June 2006-April 2011 is used for this study. Figure 2 shows deep convective cloud top pixels exceeding $15 \mathrm{~km}$ (yellow), representing cloud tops in the upper half of the TTL or above, and $17 \mathrm{~km}$ (red), representing cloud tops above the approximate height of the CPT during all December-January-February (DJF) seasons (top panel) and June-July-August (JJA) seasons (bottom panel). Note that there can be several events per pixel shown. These distributions differ in their geographical details from previous estimates based on TRMM rain rates (Liu and Zipser, 2005), in particular over land. This is in part due to CloudSat's sampling of 01:30 a.m./p.m. LT which will tend to miss the most intense deep convective events over land, known to occur during late afternoon/early evening (Liu and Zipser, 2005). Differences likely also arise from using direct observations of clouds (CloudSat) versus proxy information (TRMM). Table 1 provides bulk reference statistics for the distributions shown in Fig. 2.

In order to reveal the deep convective temperature signal in the TTL, an investigation of the temperature anomaly around the time and location of a deep convective event is necessary. This requires a high-resolution temperature data set with good spatial and temporal coverage, which ideally does not rely on model output. Here, deep convective cloud top pixels are collocated with COSMIC global positioning 

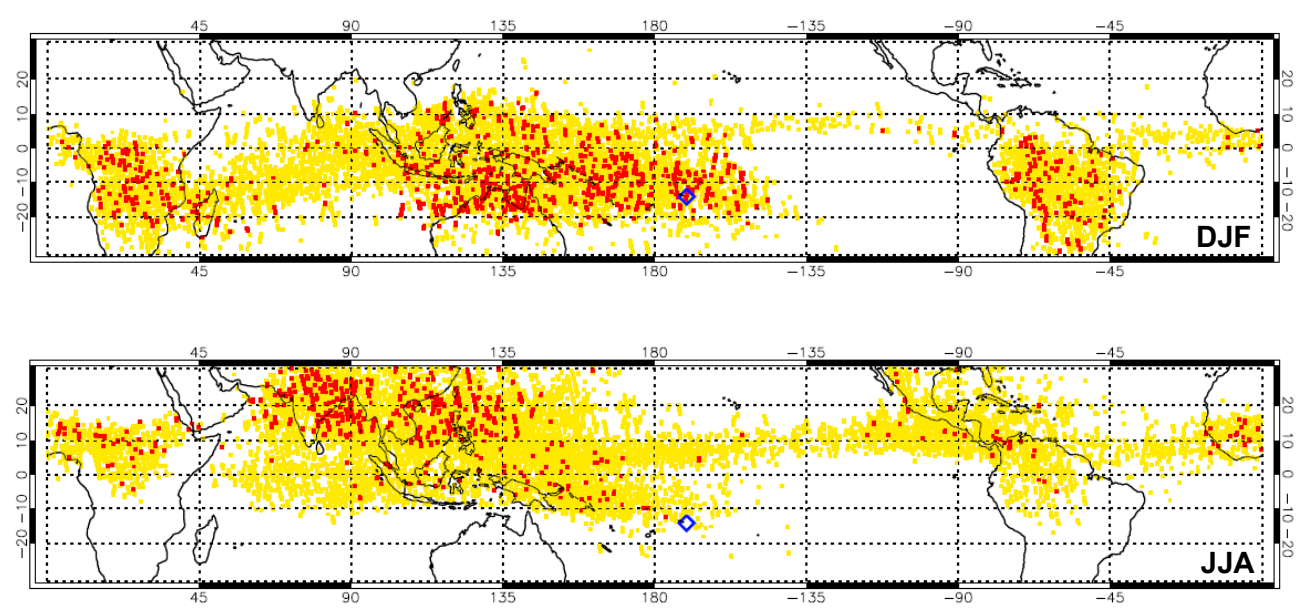

Fig. 2. Spatial distribution of deep convective cloud top pixels greater than $15 \mathrm{~km}$ (yellow) and greater than $17 \mathrm{~km}$ (red) during DJF (top) and JJA (bottom). The location of the SHADOZ station American Samoa is marked with a blue diamond.

Table 1. Percentage of all deep convective cloud top pixels greater than a threshold height, within given latitude range. Based on CloudSat 2B-CLDCLASS data for the period June 2006-April 2011.

\begin{tabular}{ccccc}
\hline & DJF $\left[20^{\circ} \mathrm{S}, 0\right]$ & DJF $\left[10^{\circ} \mathrm{S}, 10^{\circ} \mathrm{N}\right]$ & $\mathrm{JJA}\left[0,20^{\circ} \mathrm{N}\right]$ & $\mathrm{JJA}\left[10^{\circ} \mathrm{S}, 10^{\circ} \mathrm{N}\right]$ \\
\hline$>15 \mathrm{~km}$ & 17 & 14 & 14 & 10 \\
$>17 \mathrm{~km}$ & 0.8 & 0.5 & 0.3 & 0.1 \\
\hline
\end{tabular}

system (GPS) temperature profiles. Like CloudSat, the COSMIC mission provides recent data with global coverage; together they allow for characterization of the deep convective temperature signal in the TTL based purely on observational data with unprecedented detail and spatial coverage. Within 17 months of its launch in April 2006, the COSMIC mission achieved global coverage with $\sim 2000$ soundings per day (Anthes et al., 2008). COSMIC uses radio occultation described extensively by Kursinski et al. (1997). This technique exploits the bending angle to calculate the vertical profile of refractivity. The equation below, taken from Anthes et al. (2008), shows that the refractive index depends on temperature $(T ; \mathrm{K})$, pressure $(p ; \mathrm{hPa})$, partial pressure of water vapor $(e ; \mathrm{hPa})$, and electron density $\left(n_{\mathrm{e}}\right.$; number of electrons per cubic meter), where $f$ is the frequency of the transmitter $(\mathrm{Hz})$.

$N=77.6 \frac{p}{T}+3.73 \times 10^{5} \frac{e}{T^{2}}+4.03 \times 10^{7} \frac{n_{\mathrm{e}}}{f^{2}}$

Below $90 \mathrm{~km}$, the refractive index depends only on the dry atmospheric density and water vapor density (the first two terms on the right hand side of the equation). The water vapor contribution to the refractive index only becomes important where temperature is greater than $250 \mathrm{~K}$ (Kursinski et al., 1996), i.e. below about $7-8 \mathrm{~km}$ in the tropics. The temperature is derived from refractive index through integration of the hydrostatic equation. COSMIC uses data assimilation of COSMIC GPS temperature profiles and European Cen- tre for Medium-Range Weather Forecasts (ECMWF) temperature to determine water vapor mixing ratios in the troposphere, providing a temperature profile that is consistent with both that water vapor profile and the refractive index in the lower tropical troposphere. Here, we use the assimilated temperature profiles but remark that above $\sim 7-8 \mathrm{~km}$ the temperature is essentially COSMIC GPS temperature. Our record of COSMIC GPS temperature profiles are from April 2006-December 2010, mostly overlapping the time period of CloudSat data, and profiles extend from the surface up to $40 \mathrm{~km}$ and have $200 \mathrm{~m}$ vertical resolution. They are available for download at http://cosmic-io.cosmic.ucar.edu/cdaac/ products.html.

\section{Deep convective temperature signal based on SHADOZ ozone and temperature data}

Several studies have examined the connection between vertical distribution of tropospheric ozone in the tropics and deep convection. Folkins et al. (1999) found ozone to be useful as an indicator of deep convection by identifying correlated variability between upper tropospheric ozone and the lapse rate. The lapse rate transition in the upper troposphere (i.e. LRM) coincides with the exponential increase of ozone into the stratosphere. This indicates that the ozone increase is associated with the reduction of convective transport from the surface. Folkins et al. (2002) used the SHADOZ dataset 
to further this research, noting the average profile of ozone is " $\mathrm{S}$ " shaped, with the minimum ozone concentration located at the surface, a local maximum in the lower troposphere $(\sim 6.5 \mathrm{~km})$, a local minimum in the upper troposphere $(\sim 12 \mathrm{~km})$, and an exponential increase into the stratosphere. The ozone minimum in the upper troposphere indicates convective influence caused by transport of low ozone values from the boundary layer. However, results also showed that considerable differences exist between SHADOZ stations, with the lowest upper tropospheric ozone minimum concentrations occurring at stations with active marine convection. Solomon et al. (2005) found that the southwest Pacific more frequently observes low ozone concentration in the upper troposphere or so-called reduced ozone events, when compared to other regions. The location of these reduced ozone events corresponds to a region of high sea surface temperatures and frequent deep convection. While the above studies highlight the suitability of ozone as a tracer of deep convection, the present study further analyzes convective influence on ozone profiles. Our aim is to identify and quantify the deep convective temperature signal associated with reduced ozone events.

In order to identify this signal, we first investigate the temperature profiles associated with the $10 \%$ lowest ozone anomalies at a given vertical level around the main deep convective outflow layer. Note that this results in a different group of profiles for each vertical level where the ozone anomalies are taken. The temperature profiles are obtained from the radiosonde measurements accompanying each ozonesonde ascent. All anomalies are created by deseasonalization, which removes the appropriate long-term daily mean profile. Because the level of deep convective outflow varies, the temperature signal associated with the $(10 \%$ lowest) ozone anomalies is taken at each $50 \mathrm{~m}$ interpolated level between $10-22 \mathrm{~km}$. We expect a corresponding temperature anomaly profile that exhibits the result of upper tropospheric warming associated with enhanced latent heating, as well as near tropopause cooling associated with the "convective cold top" (see introduction). Figure 3 shows the temperature anomaly at various heights, contoured as a function of the height at which the low ozone anomaly is taken. Anomalies that are significantly different from zero (at the $95 \%$ level, using a t-test) appear in color.

A deep convective signal in the temperature structure is evident for low ozone anomalies between $12-18 \mathrm{~km}$. This suggests that profiles with anomalously low ozone concentrations in the upper troposphere and TTL are indeed convectively influenced; deep convection, which triggers the transport of reduced surface ozone concentrations to the upper troposphere, also warms the upper troposphere (most strongly near the level of main convective outflow, $\sim 12 \mathrm{~km}$ ) and cools the TTL (more precisely the upper half of the TTL above $\sim 15 \mathrm{~km}$, most strongly near the CPT, $\sim 17 \mathrm{~km}$ ). The strongest convective signal occurs for low ozone anomalies near $16 \mathrm{~km}$, i.e. somewhat above the level of main deep convective outflow $(\sim 12 \mathrm{~km})$. Because temperature anomalies

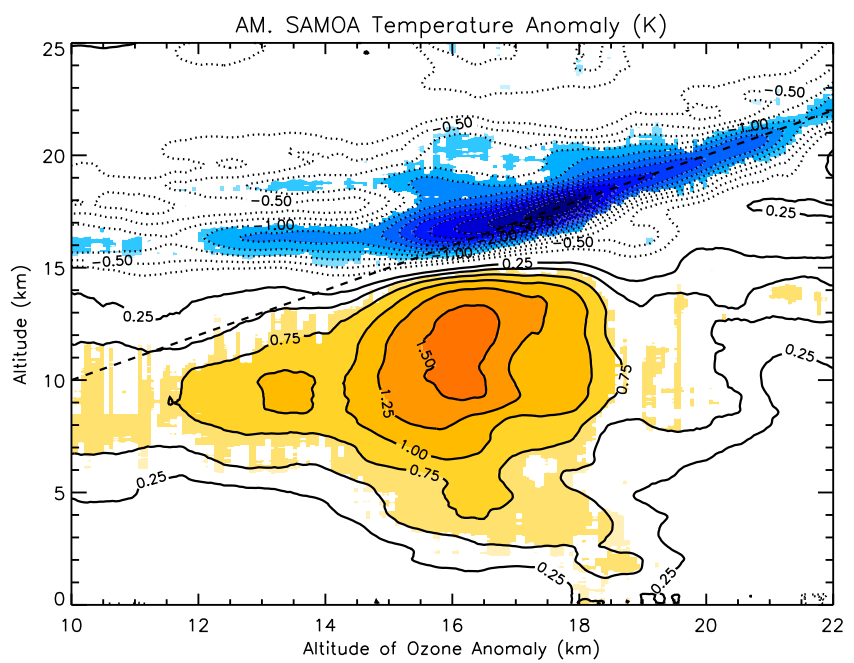

Fig. 3. The average temperature anomaly contoured as a function of altitude (ordinate), corresponding to the $10 \%$ lowest ozone anomalies taken at various altitudes (abscissa), at American Samoa. The contour interval is $0.25 \mathrm{~K}$, with dotted contours indicating negative anomalies. Anomalies that exceed the $95 \%$ significance level appear in color. The 1:1 line appears dashed. Approximate sample size for each group of $10 \%$ lowest ozone anomalies is 40 .

appear convectively influenced for a range of ozone anomaly heights (between 12-18 km), reduced ozone events appear to manifest themselves within the entire layer. Cooling at the level of the ozone anomaly in the stratosphere (along the dashed line in Fig. 3, above $\sim 17 \mathrm{~km}$ ) is the result of anomalies in vertical motion: ozone is a quasi-passive tracer at these altitudes; anomalously strong upwelling results in advection of anomalously low ozone from below with concurrent local cooling.

A somewhat surprising feature in the tropospheric temperature anomalies in Fig. 3 is the lack of cold anomalies in the lower troposphere and near the surface, which have been found in composite deep convective life cycles (e.g. Sherwood and Wahrlich, 1999; Mitovski et al., 2010). The coherent warm anomalies throughout the tropospheric column in Fig. 3 are however consistent with those associated with low-frequency variability, such as the MJO (e.g. Kiladis et al., 2005) and ENSO (e.g. Kiladis et al., 2001). Low ozone anomalies in the upper troposphere and TTL have been found to be associated with El Niño conditions (Randel and Thompson, 2011), with corresponding temperature anomalies that qualitatively resemble the structures in Fig. 3. Inspecting the ENSO Nino3.4 index (http://www.cpc.ncep. noaa.gov/data/indices/sstoi.indices) confirms that most of the $10 \%$ lowest ozone anomalies occur during El Niño conditions. However, we have repeated our analysis for El Niño and La Niña conditions separately (i.e. with ozone and temperature anomalies defined relative to average El Niño and La Niña conditions, respectively), and obtained essentially 


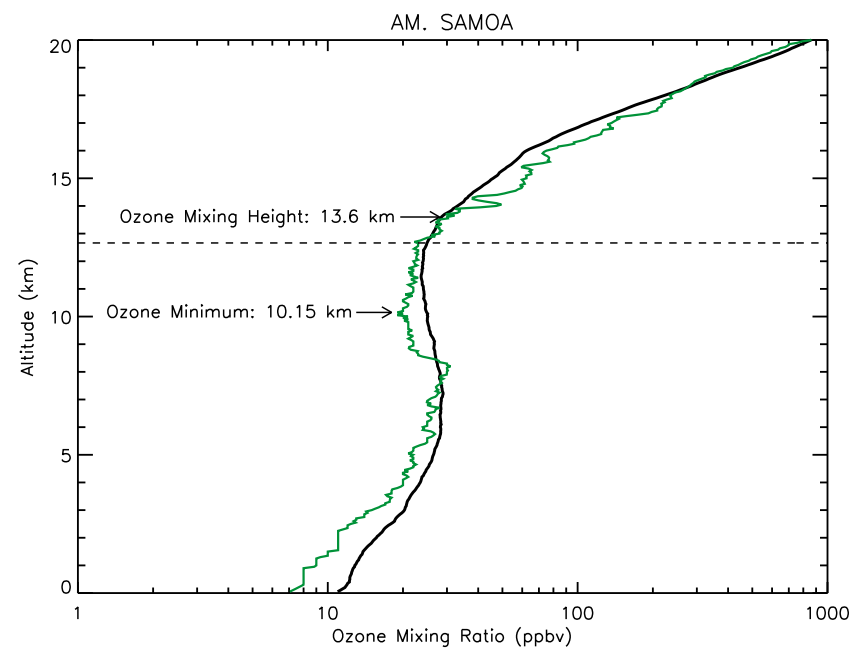

Fig. 4. The vertical ozone profile (green line) from 8 March 2006 at American Samoa demonstrating that ozone can remain relatively low over a layer of substantial thickness in the upper troposphere. The ozone minimum occurs at $10.15 \mathrm{~km}$ and the ozone mixing height at $13.6 \mathrm{~km}$ (corresponding to the maximum altitude ozone is less than $33.4 \mathrm{ppbv}$ - the seasonally average ozone concentration at the LNB). The seasonal mean (March-April-May) ozone profile is plotted with a black line. The horizontal dashed line indicates the seasonal mean height of the LNB.

the same temperature anomaly structures as shown in Fig. 3, albeit with reduced amplitudes (not shown). Other lowfrequency variability such as the MJO may be responsible for the generic temperature signal obtained here.

Having established that there is a convective temperature signal associated with low ozone anomalies at the level of convective outflow, we now look at diagnostics to better quantify the depth of deep convective influence on individual ozone profiles. The "ozone minimum" diagnostic, discussed in previous studies (Gettelman and Forster, 2002; Gettelman and Birner, 2007), provides a way to quantify the nature of the " $\mathrm{S}$ " shape in individual profiles by identifying the location and strength of the upper tropospheric ozone minimum. Here, the ozone minimum is defined as the lowest ozone concentration above $6.5 \mathrm{~km}$ in a given profile. The height requirement is in place to ensure the event is upper tropospheric, and $6.5 \mathrm{~km}$ is chosen because it is the level in the "S" shaped ozone profile where concentrations begin to decrease toward the upper tropospheric minimum. The ozone minimum generally occurs just above the LRM (Gettelman and Forster, 2002).

Figure 4 shows an individual ozone profile at American Samoa chosen because it exemplifies the "S" shape described by Folkins et al. (2002). However, it also demonstrates that ozone may remain low over an extended layer in the upper troposphere, a typical structure seen in the majority of ozone profiles. In the particular individual profile shown the ozone minimum occurs at $10.15 \mathrm{~km}$; however, ozone concentrations
Table 2. Seasonal mean LNB ozone values (in ppbv) at American Samoa (for the period 1998-2009).

\begin{tabular}{cccc}
\hline DJF & MAM & JJA & SON \\
\hline 30.2 & 33.4 & 35.4 & 38.4 \\
\hline
\end{tabular}

are similar to the concentration at the minimum between $\sim 9-14 \mathrm{~km}$, which renders the precise value of the ozone minimum height somewhat irrelevant. Rather than identifying the upper tropospheric ozone minimum, a new diagnostic, "ozone mixing height", is established to determine the maximum height up to which reduced ozone concentrations are observed. We define this ozone mixing height as the maximum altitude at which ozone concentrations below a given threshold are found. Reduced ozone concentrations in the upper troposphere result from convective transport from the boundary layer. However, ozone concentrations as low or lower than those found in the marine boundary layer are only rarely found in the upper troposphere. This is because entrainment dilutes convective updrafts with environmental air of higher ozone concentrations. A value for the threshold in the definition of the ozone mixing height based on concentrations in the boundary layer would therefore require a (somewhat subjective) dilution factor or offset, which would introduce an undesirable subjectivity and degree of freedom. Instead, we opt for utilizing the level of neutral buoyancy (LNB) in defining the threshold concentration as described below.

Defined as the level at which a parcel rising adiabatically within a convective updraft will no longer be positively buoyant, the LNB offers a useful way to quantify the potential upper extent of deep convective clouds. Once a parcel reaches this level, it will likely detrain and mix with the environment. Because low ozone concentrations at the surface have the potential to be mixed up to the LNB via deep convective updrafts, this parameter may be thought of as an upper bound for vertical ozone mixing. Thus, the threshold concentration for the "ozone mixing height" diagnostic is determined as the seasonally average of the ozone concentrations at each profile's LNB. This threshold concentration should provide a typical concentration of ozone at the detrainment level. The seasonal mean threshold values are listed in Table 2 for reference. The LNB is obtained here assuming pseudo-adiabatic ascent and using an air parcel origin that maximizes convective available potential energy (CAPE). The CAPE calculation is standard in that it neglects entrainment and does not take into account latent heat of fusion. For the individual profile shown in Fig. 4, the ozone mixing height occurs at $13.6 \mathrm{~km}$, which is the maximum altitude ozone is less than 33.4 ppbv - the seasonal (in this case March-April-May, MAM) mean LNB ozone concentration. Table 2 lists all seasonal mean LNB ozone concentrations for reference. 
For both diagnostics, we produce composites with respect to either the height of the ozone minimum or the ozone mixing height, in order to determine the temperature fields associated with varying depths of deep convective influence on ozone.

Figure 5 (top) displays the composite temperature anomaly profiles sorted by the ozone mixing height, where colored lines indicate that the anomaly meets the $95 \%$ significance level. A strong convective temperature signal characterized by an anomalously warm upper troposphere and an anomalously cold upper TTL, with minimum temperatures peaking at the CPT, appears for the $10 \%$ highest ozone mixing heights. A similar, though somewhat weaker signal appears for anomalously high, but not extremely high ozone mixing heights (labeled 70-90\% in the plot). These signals represent the large-scale temperature signature of deep convection, and suggest anomalously high ozone mixing heights in fact represent convectively influenced ozone profiles. The overall structure of these convective temperature signals is very similar to that described in Fig. 3. Again, no near surface or lower to mid tropospheric cold anomaly is evident (see discussion around Fig. 3). It is also interesting to note the $10 \%$ lowest ozone mixing heights (red curve in Fig. 5) show a reverse signal (cool upper tropospheric anomaly, warm TTL anomaly), i.e. a clear transition between a convective and non-convective regime is evident. While there is a strong change in the temperature at the approximate level of CPT, the average height of the CPT does not change between composite groups. Compositing lapse rate profiles with respect to the ozone mixing height reveals a shift in the height of the lapse rate decrease associated with the transition into a stratospheric regime; high altitude ozone mixing heights have higher altitude lapse rate decreases (Paulik, 2011).

Figure 5 (bottom) shows similar composites using the ozone minimum height diagnostic. There is also evidence of a convective temperature signal associated with the $10 \%$ highest ozone minimum heights; however, the magnitude of the signal is strongly reduced when compared to the highest ozone mixing heights. Furthermore, the $10 \%$ lowest ozone minimum heights do not show a clear reverse signal, and a transition from the convective to the non-convective regime is not readily apparent.

In this section, we have found temperature to have a deep convective signal associated with the reduced ozone events. Results suggest that using the LNB in connection with vertical ozone profile is effective for determining convective influence. Results based on the ozone minimum diagnostic do not provide as clear a picture of this convective influence.

\section{Deep convective temperature signal based on CloudSat and COSMIC data}

Having identified a deep convective temperature signal associated with reduced ozone events, we now investigate the
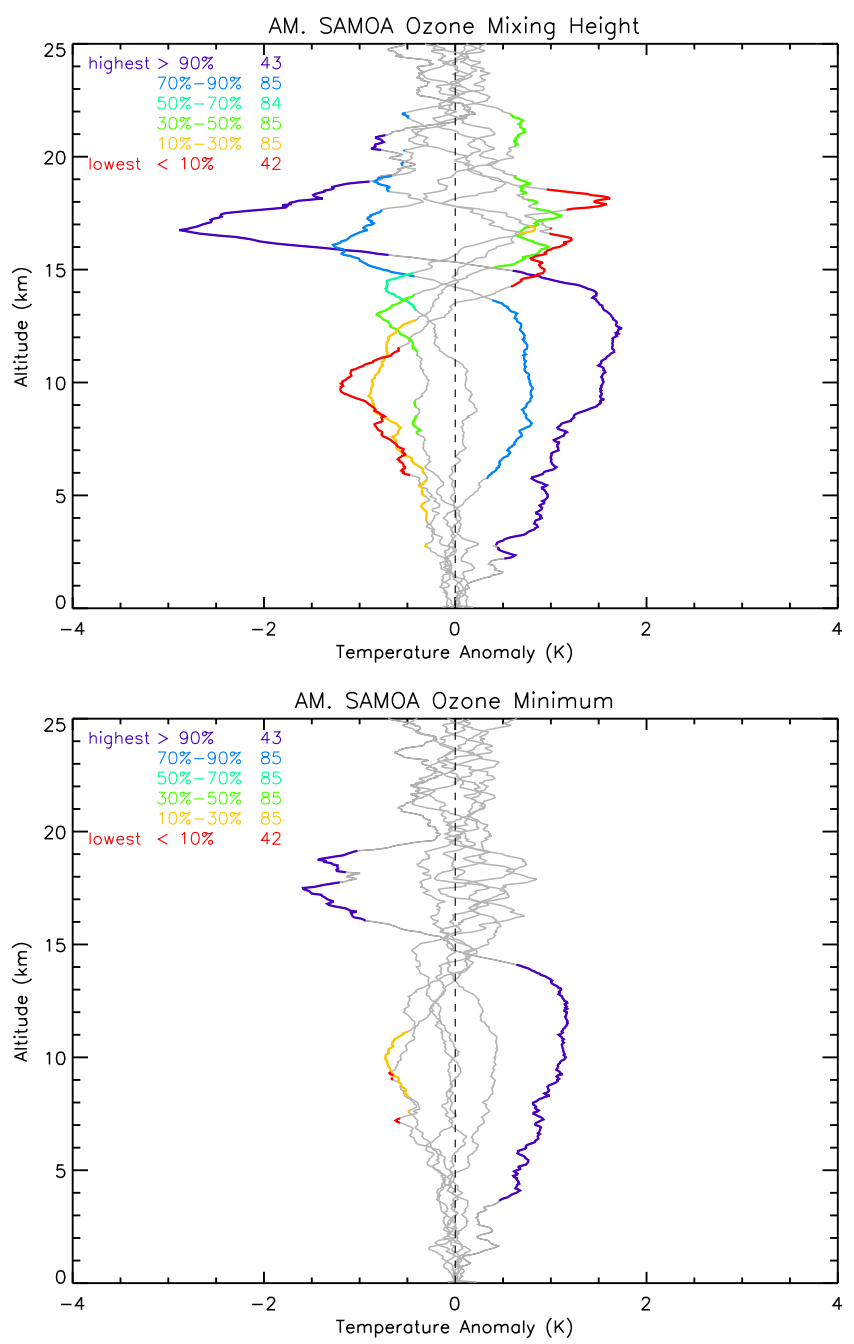

Fig. 5. Average profiles of temperature anomaly composited by (top) the height of the ozone mixing height and (bottom) the ozone minimum. Colored lines indicate where anomalies exceed the $95 \%$ significance level (with purple - highest and red - lowest heights). The number of profiles that make up each composite group appears next to the percentage.

signal associated with direct observations of deep convective clouds. Our approach collocates deep convective cloud top pixels identified by CloudSat 2B-CLDCLASS with COSMIC GPS temperature profiles. Recently, Chae et al. (2011) have used co-located CloudSat, Cloud-Aerosol Lidar and Infrared Pathfinder Satellite Observation (CALIPSO), and Microwave Limb Sounder (MLS) data to study temperature variations associated with thick, thin, and multi-layered clouds in the TTL. However, their cloud classification did not single out deep convective clouds and their temperature product (from MLS) has coarse vertical resolution of 3-4 km, limiting a detailed study of deep convective influence on TTL temperatures. 
COSMIC GPS temperature profiles are deseasonalized by creating monthly mean profiles at each point on a $5^{\circ} \times 5^{\circ}$ grid and removing the long-term monthly mean profile interpolated to each profile location. Given that the GPS signal enters the atmosphere at an angle, the interpolation accounts for variations in profile location at each vertical level. The presented results collocate deep convective clouds to the location of the sounding at $17 \mathrm{~km}$, the approximate height of the CPT; however, results are similar when collocating to the location of the sounding in the upper troposphere where deep convective heating is expected. The method ignores the time it takes for a GPS temperature profile to pass through the atmosphere (this is of the order of a few minutes, which is much shorter than the shortest possible distance in time used for the collocation). The distance between deep convective clouds and temperature profiles is computed using the Great Circles Distance Formula:

Distance $=$

$a \times \arccos \left[\sin \varphi_{1} \sin \varphi_{2}+\cos \varphi_{1} \cos \varphi_{2} \cos \left(\lambda_{2}-\lambda_{1}\right)\right]$.

In this formula, $a$ is the radius of the earth $(6378.7 \mathrm{~km}), \lambda$ is longitude, and $\varphi$ is latitude, with indices 1 and 2 referring to the locations of the cloud and temperature observations, respectively. Variations in $a$ are ignored because only the tropics are considered.

Using this method, we are able to quantify the temperature signal of deep convection, characterized by an anomalously warm upper troposphere and an anomalously cold upper TTL, for temperature profiles in proximity to deep convective cloud top pixels. Results indicate the temperature signal is strongly dependent on the height of the deep convective cloud top pixel. Figure 6 shows the (top) DJF and (bottom) JJA average profiles of the temperature anomaly within $1000 \mathrm{~km}$ associated with various deep convective cloud top pixel heights, where colored lines indicate anomalies that exceed the $99 \%$ significance level. We have restricted the latitude in each season in order to account for the seasonal shift in deep convection; for DJF we use deep convective cloud top pixels between $\left[20^{\circ} \mathrm{S}, 0^{\circ}\right]$, while for JJA we use deep convective cloud top pixels between $\left[0^{\circ}, 20^{\circ} \mathrm{N}\right]$. This improves the available statistics but does not lead to qualitative differences compared to using $\left[10^{\circ} \mathrm{S}, 10^{\circ} \mathrm{N}\right]$ (not shown).

It is clear that the strongest convective temperature signal appears for temperature profiles in proximity to the highest deep convective clouds in both seasons. The temperature signal for deep convective cloud tops greater than $17 \mathrm{~km}$ in DJF shows warm anomalies between $3-15 \mathrm{~km}$, strongest $(\sim 1 \mathrm{~K})$ at $\sim 12 \mathrm{~km}$, and cold anomalies between $15-18 \mathrm{~km}$, strongest $(\sim-1.5 \mathrm{~K})$ at $\sim 17 \mathrm{~km}$. The magnitudes of these strongest anomalies is smaller, and occurs at lower altitudes for deep convective cloud tops between 16-17 km (maximum cold anomaly of $-0.5 \mathrm{~K}$ occurs at $\sim 16 \mathrm{~km}$ ). Cold and warm anomalies shift down and their magnitude is further reduced for deep convective cloud tops between $15-16 \mathrm{~km}$, and the deep convective temperature signal disappears for deep con-
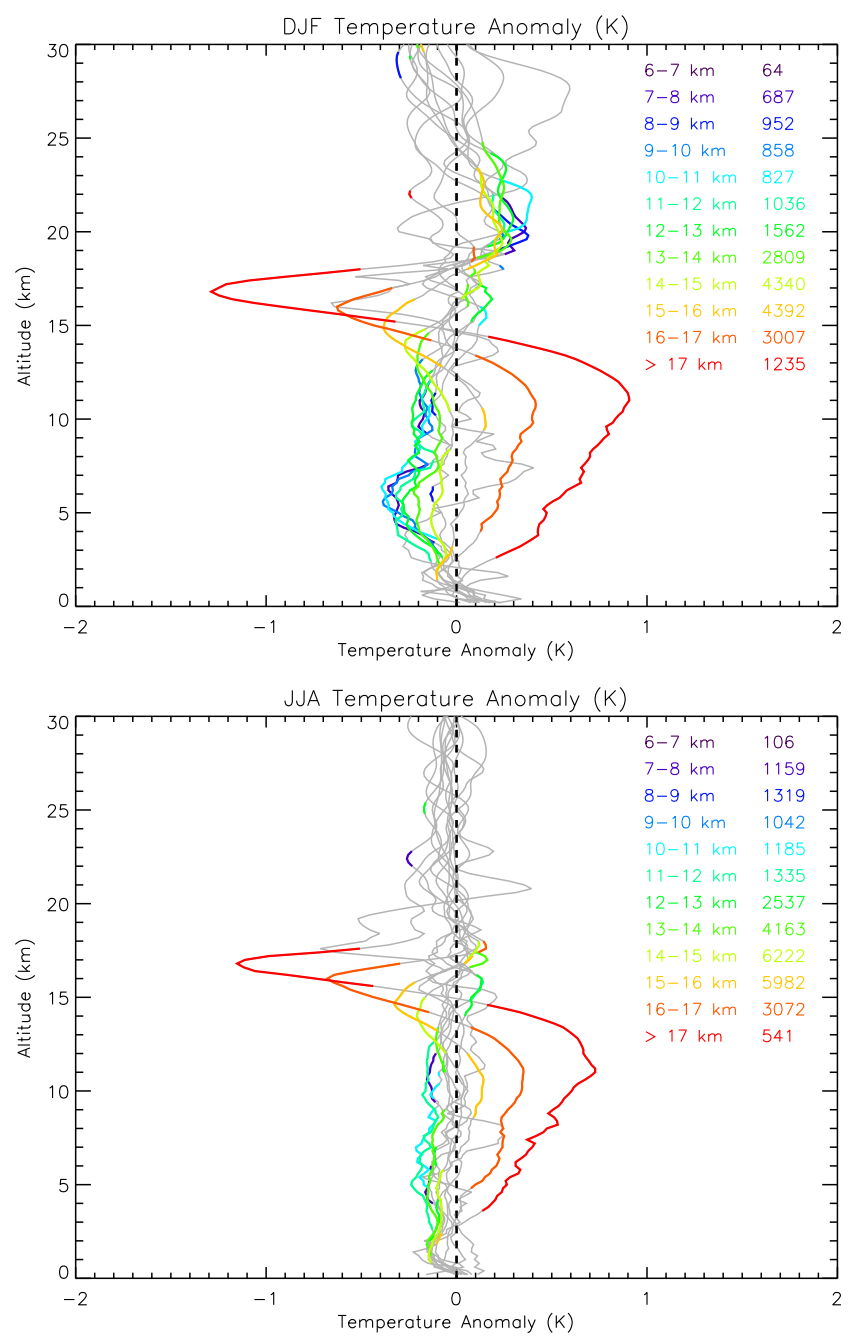

Fig. 6. Average temperature anomaly profiles for GPS soundings within $\pm 6 \mathrm{~h}$ and $1000 \mathrm{~km}$ of a maximum deep convective cloud greater than $17 \mathrm{~km}$ (red), between 16-17 km (orange), between 15$16 \mathrm{~km}$ (yellow), and so on, during (top) DJF and (bottom) JJA. Anomalies that exceed the $99 \%$ significance level appear in color. The number of profiles that go into each anomaly profile is given on the right side of the figure.

vective cloud tops lower than $15 \mathrm{~km}$. This suggests that only the deep convective clouds that penetrate into the upper half of the TTL or above ( $>15 \mathrm{~km}$ ) affect TTL temperature. And, while deep convective cloud top pixels greater than $17 \mathrm{~km}$ are rare and only occur in localized regions (Fig. 2), they appear to have the greatest impact. Note how the peak cold anomalies for clouds above $15 \mathrm{~km}$ center around the cloud top height of the respective bin, roughly confirming the recent findings of Chae et al. (2011) that cold anomalies exist up the cloud top.

Note that for cloud tops between $15-16 \mathrm{~km}$ an additional warm anomaly exists in the lower stratosphere (between about $18-23 \mathrm{~km}$ altitude), suggesting a wave like response 
to deep convection (cf. Kiladis et al., 2009). This wave like response tends to show up more clearly when using cloud statistics between $\left[10^{\circ} \mathrm{S}, 10^{\circ} \mathrm{N}\right]$. However, our approach will in general lead to averaging across a range of convectively coupled wave signals such that signals due to individual wave types will be mostly averaged out. Chae et al. (2011) also find a similar warm anomaly, although only $\sim 2 \mathrm{~km}$ above cloud top in their case, which they attribute to subsidence warming forced by convective outflow.

A weak reverse deep convective temperature signal exists for anomalously low cloud tops (below $\sim 13 \mathrm{~km}$ ) with an anomalously cold troposphere (peaking around $-0.3 \mathrm{~K}$ near $6 \mathrm{~km}$ during DJF) and an anomalously warm lower stratosphere (peaking around $+0.3 \mathrm{~K}$ near $20 \mathrm{~km}$ during DJF). Generally similar structures to the above described are found during JJA (Fig. 6 bottom), with however somewhat weaker amplitudes in the temperature anomalies. As in the analysis of reduced upper tropospheric ozone events in the previous section no lower tropospheric or near surface cold anamalies are found.

Given the TTL temperature signal due to deep convection shows up most clearly for deep convective cloud tops above $17 \mathrm{~km}$, the remainder of this section investigates the temperature signal in proximity to deep convective cloud top pixels greater than that threshold. First, the dependence of the signal on the distance between the deep convective cloud top pixel and the COSMIC GPS temperature profile is investigated. Figure 7 shows the temperature anomaly contoured as a function of the distance between the deep convective cloud top pixel and the COSMIC GPS temperature profile and altitude. Anomalies appear in color when they exceed the $99 \%$ significance level. As expected, the magnitude of the anomalies decays with increasing distance. It is also apparent that the anomalies decay faster with increasing distance in JJA, becoming insignificant beyond $\sim 1500 \mathrm{~km}$. The anomalies in DJF are more widespread, having an impact out to $\sim 3500 \mathrm{~km}$ away from the convective event. We conclude that the signal is large-scale, having an impact on TTL temperatures as far as several thousand kilometers away from the deep convective event, but there is evidence that a distinct difference in the spatial scale exists between seasons. The horizontal scale of the anomalies suggests the convective event to be embedded in a large-scale organized convective complex.

Using our collocation method, we can also investigate the time evolution of a convective event to provide insight into the system's lifecycle. Figure 8 shows the average temperature anomaly within $1000 \mathrm{~km}$ of a deep convective cloud top pixel greater than $17 \mathrm{~km}$ contoured as a function of lag, where colored anomalies exceed the $99 \%$ significance level. During DJF, the convective temperature anomaly starts to exceed $0.5 \mathrm{~K}$ in the upper troposphere $\sim 4$ days preceding the deep convective event. Evidence of a strong signal earlier than the observed deep convective cloud (less than day 0) suggests convective influence began before CloudSat observed
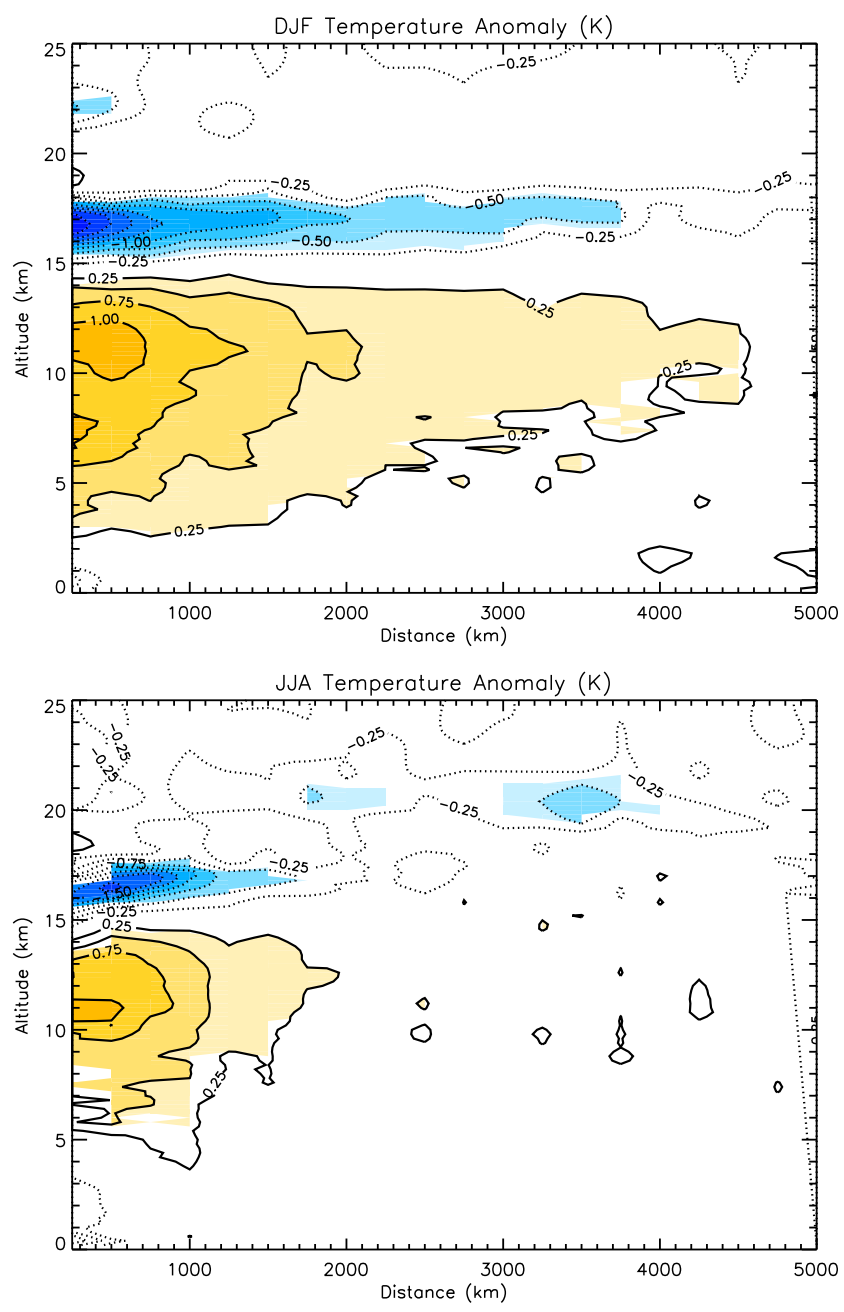

Fig. 7. Temperature anomaly contoured as a function of distance between CloudSat and COSMIC GPS measurements (within $\pm 6 \mathrm{~h}$ ) and altitude, corresponding to events with deep convective cloud top pixels above $17 \mathrm{~km}$, for (top) DJF and (bottom) JJA. Anomalies that exceed the $99 \%$ significance level appear in color. Orange and red colors correspond to positive anomalies, blue colors correspond to negative anomalies.

the deep convective cloud top. A strong signal up to a week after the convective event ( $\sim 8$ days in DJF) indicates its persistence in time. The temperature anomaly in JJA is significantly shorter-lived demonstrating a noteworthy difference between seasons, similar to the difference in spatial scales. We note that the negative anomaly at the CPT appears to somewhat precede the strongest upper tropospheric warming, perhaps indicating destabilization of the upper troposphere prior to a convective event. We also remark that there is an indication for a low frequency signal reminiscent of the MJO when extending to much larger lags than shown in Fig. 8, although structures become very noisy at these large lags due to current sample sizes being relatively small. 

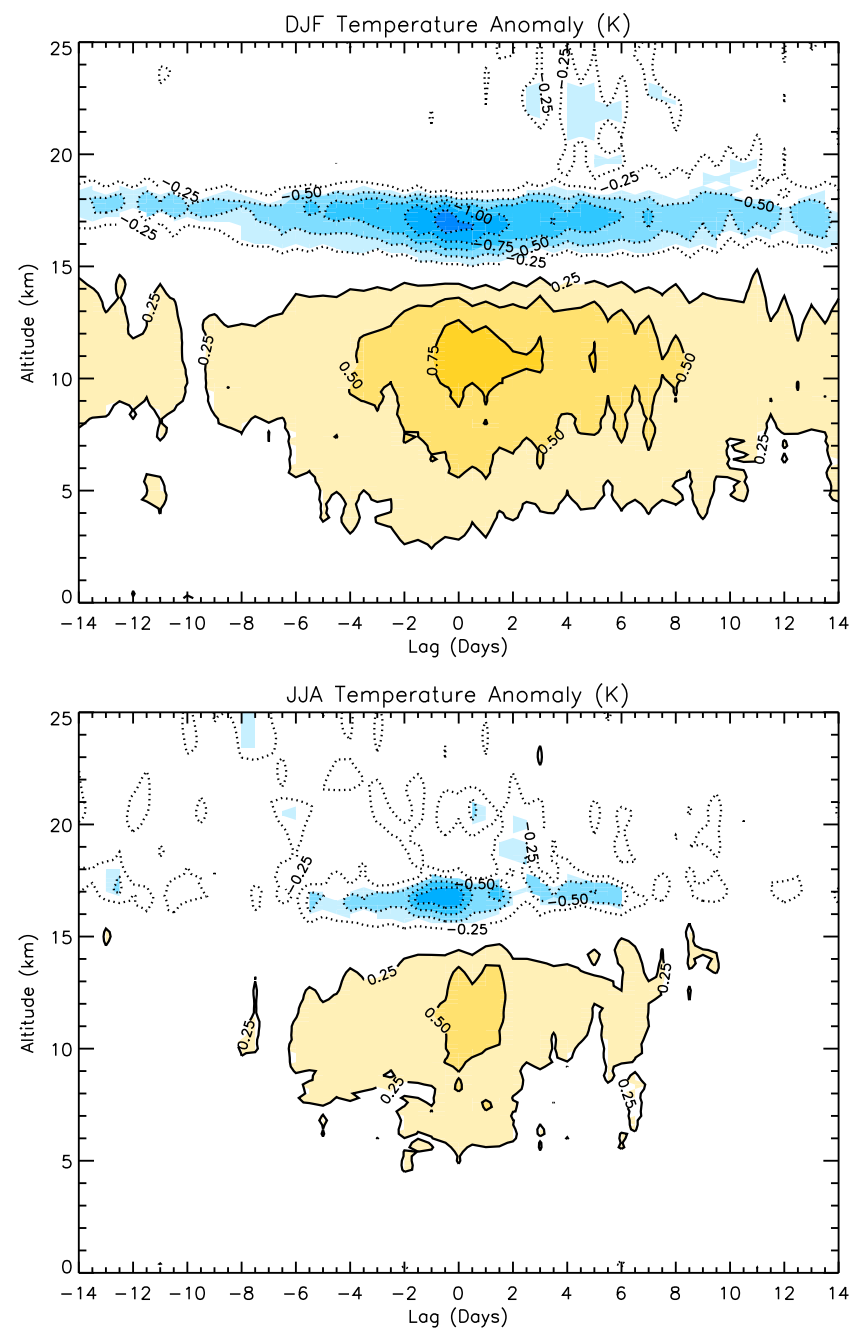

Fig. 8. Temperature anomaly within $1000 \mathrm{~km}$ of a deep convective cloud with cloud top greater than $17 \mathrm{~km}$, contoured as a function of time and altitude during (top) DJF and (bottom) JJA. The contour interval is $0.25 \mathrm{~K}$, and anomalies that exceed the $99 \%$ significance level appear in color. Orange and red colors correspond to positive anomalies, blue colors correspond to negative anomalies.

This section successfully revealed the convective temperature signal associated with observed deep convective clouds. Results suggest only convection that penetrates into the upper half of the TTL ( $>15 \mathrm{~km}$ ) has a significant impact on the temperature distribution of the TTL. Now, using results from Sect. 3, we look to draw conclusions about deep convection in the upper half of the TTL.

\section{Discussion}

We have used two approaches to better understand the temperature signal associated with deep convection. The first approach utilized the SHADOZ dataset, investigating ozone as a tracer for deep convection. A convective signal in temper- ature was identified for the $10 \%$ lowest ozone anomalies between 12-18 km (Fig. 3), confirming ozone as an effective tracer for deep convection. The strongest signal was observed for low ozone anomalies above $15 \mathrm{~km}$, corresponding to the upper half of the TTL. We quantified convectively influenced upper tropospheric ozone from individual ozone profiles based on two diagnostics: the height of the lowest ozone mixing ratio (the "ozone minimum") and the height up to which ozone stays below a certain threshold concentration (the "ozone mixing height"). The level of neutral buoyancy (LNB) was utilized to define the threshold for the ozone mixing height. Compositing with respect to the ozone mixing height, as opposed to the ozone minimum height, better separated profiles in terms of their convective temperature signal; the $10 \%$ highest ozone mixing heights reflect profiles with a strong convective temperature signal. Thus, we conclude that ozone mixing height is a more effective diagnostic for assessing the deep convective temperature signal.

The second approach used CloudSat 2B-CLDCLASS data. Identified deep convective cloud top pixels were collocated with COSMIC GPS temperature profiles. The strongest convective temperature signal appeared for deep convective cloud top pixels within the upper half of the TTL or above ( $>15 \mathrm{~km}$ ), consistent with our results based on ozone (see above). Results show that the convective temperature signal is large-scale and persistent in time, with a distinct difference between the seasons: during DJF the signal tends to be larger in scale and more persistent in time than during JJA. In summary, individual approaches based on SHADOZ and CloudSat/COSMIC GPS revealed distinct deep convective temperature signals in the TTL. We will now combine both approaches in order to provide a more synergistic understanding of deep convective influence on temperature in the TTL.

The location of the American Samoa SHADOZ stations relative to the occurrence of deep convective cloud top pixels as identified by CloudSat is shown in Fig. 2. To better understand convection at American Samoa, we produce a climatology of deep convective cloud top heights by identifying cloud top pixels within $1000 \mathrm{~km}$ of this station location. Figure 9 (top) presents this climatology, where the relative frequency of identified deep convective cloud top pixels is contoured as a function of month and height. Here it is seen that deep convection most frequently occurs in December-April. These months display a bimodal distribution in deep convective cloud top pixel height with a dominant peak near $15 \mathrm{~km}$ and a secondary peak between $7-8 \mathrm{~km}$. This secondary peak seems to indicate the presences of high cumulus congestus cloud tops, falsely categorized as deep convective cloud tops. Plotted over the deep convective cloud climatology is the annual cycle of the LNB (only using those located above $6.5 \mathrm{~km}$ ) and the ozone mixing height. The LNB and ozone mixing height tend to fall within $1 \mathrm{~km}$ of the height of the maximum frequency of deep convective cloud tops, with similar seasonal cycles. In contrast, the LRM and ozone minimum 

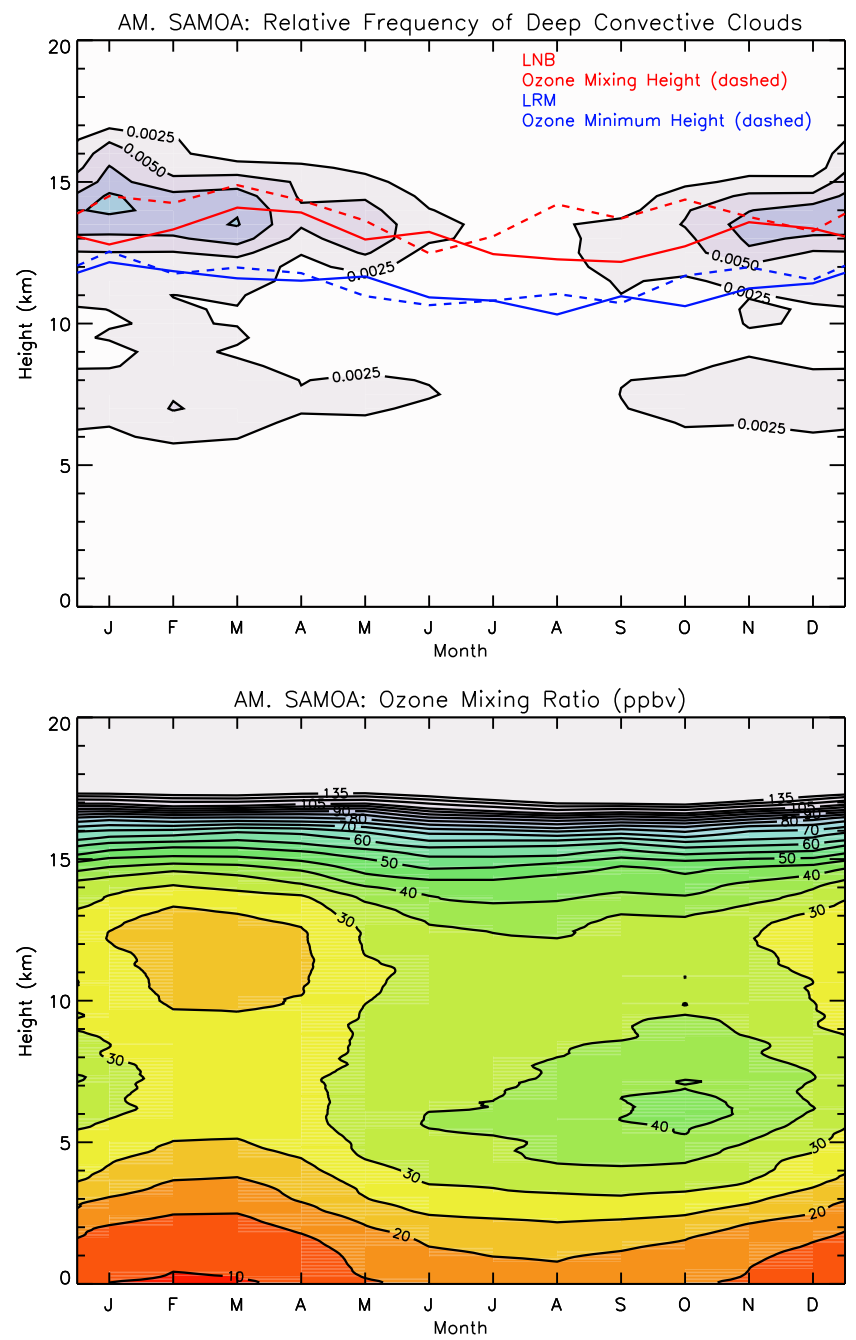

Fig. 9. (Top) annual cycle of the relative frequency distribution of deep convective cloud top heights within $1000 \mathrm{~km}$ of American Samoa (contours). Also included is the annual cycle of the LNB (red, solid), the ozone mixing height (red, dashed), the LRM height (blue, solid), and the ozone minimum height (blue, dashed). (Bottom) annual cycle of the ozone concentration (ppbv) at American Samoa, similar to Fig. 3d in Thompson et al. (2011). Orange and red colors indicate relatively low values, blue colors indicate relatively high values.

height, which roughly represent the level of main convective outflow, appear to more closely represent a lower bound of deep convective cloud tops, with a typical separation of 2$3 \mathrm{~km}$ between either the LNB or ozone mixing height and the LRM or ozone minimum height.

Figure 9 (bottom) shows the annual cycle of ozone mixing ratio contoured as a function of height at American Samoa, similar to Fig. 3d in Thompson et al. (2011). Here, it is seen that upper tropospheric ozone concentrations are lower in months with a high frequency of deep convection. For example, the $30 \mathrm{ppbv}$ contour roughly follows the height of maximum cloud top frequency $(\sim 14 \mathrm{~km})$ during the convective season, but sharply drops to lower tropospheric levels $(\sim 4 \mathrm{~km})$ during the non-convective season. At first sight, there appears to be a $\sim 1$ month lag between this ozone signal and the convective cloud signal in the top panel of Fig. 9. However, the upper tropospheric ozone minimum during February-March is in phase with the lowest boundary layer ozone values. Furthermore, mid-tropospheric ozone, which enters the updrafts through entrainment is higher during December-January than during February-March. That is, the maximum convective impact on upper tropospheric ozone likely occurs in phase with the most frequent convective clouds. A strong transition from the tropospheric convective regime toward the stratospheric chemical regime occurs between $\sim 14-15 \mathrm{~km}$ and above with a stronger gradient during the convective season. This transition roughly coincides with the LNB and maximum frequency of deep convective cloud tops. We may therefore conclude that deep convection is significant in influencing composition as high as $\sim 15 \mathrm{~km}$ during the convective season. This is somewhat higher than the level of main convective outflow $\sim 12-13 \mathrm{~km}$ (Folkins et al., 2002).

Results presented here focus on the American Samoa SHADOZ station because it has a pristine marine environment and is located well within a region of high occurrence rate of deep convection (except during JJA). We have analyzed a number of other SHADOZ stations (see Paulik, 2011) - those with similar favorable conditions (e.g. Suva, Fiji) show very similar results. However, other stations, either not located in frequently convecting regions or with more polluted boundary layers, do not show as clear signals as American Samoa.

Combining SHADOZ and CloudSat has shown that the height of deep convective cloud tops is on average well represented by the LNB, confirming recent findings by Takahashi and Luo (2012). The calculation of the LNB assumes (1) undiluted ascent (which Romps and Kuang, 2010, find to be extremely unlikely for plumes reaching TTL altitudes), and does not account for the effects of (2) latent heat due to freezing (which provides additional parcel buoyancy, e.g. Fierro et al., 2009), and (3) overshoots. Assumption (1) results in an overestimation, while both (2) and (3) result in an underestimation of the height of the LNB. The strong agreement between deep convective cloud top heights and the LNB therefore suggests that these competing neglected effects roughly cancel - the (conventional) LNB appears to effectively define the maximum vertical extent of deep convective clouds. The lapse rate maximum (LRM) height, in contrast, quantifies the main convective outflow level which tends to be located well below the highest cloud tops. Given that the diagnostic based on the ozone minimum (which is correlated to the LRM) did not reveal the convective temperature signal as well as the diagnostic based on ozone at the LNB (which is correlated with the deep convective cloud top heights), it appears that the level to which convection 
penetrates is more important than the main convective outflow level for determining convective influence on TTL temperatures. Because the convective temperature signal appeared strongest for ozone anomalies in the upper half of the TTL $(>15 \mathrm{~km})$ and for convective cloud top pixels that penetrate to the upper half of the TTL, we conclude that it is only the highest deep convective events that have a significant impact on TTL temperature and composition.

Utilizing recently developed datasets (in particular based on the Cloud Profiling Radar on CloudSat and the GPS radio occultations from COSMIC) allowed us to provide an improved quantification of the structure, scale, and persistence of convectively induced temperature variability in the TTL. The conveyed information may prove useful for the development and representation of crucial TTL properties in climate models.

Acknowledgements. This work originated out of LCP's M.Sc. thesis at Colorado State University - discussions and suggestions by her committee members (Colette Heald, Graeme Stephens, David Krueger) are gratefully acknowledged. We also thank the constructive review comments by George Kiladis and an anonymous reviewer, as well as comments on the manuscript by editor William Lahoz. LCP was funded through NASA grant \#NAS5-99237 (CloudSat). TB acknowledges current funding through a CAREER grant by the US National Science Foundation (NSF).

Edited by: W. Lahoz

\section{References}

Anthes, R. A., Kallberg, P. W., Simmons, A. J., Andrae, U., Bechtold, P., Costa, V. D., M. Fiorino, M., Gibson, J. K., Haseler, J., Hernandez, A., Kelly, G. A., Li, X., Onogi, K., Saarinen, S., Sokka, N., Allan, R. P., Andersson, E., Arpe, K., Balmaseda, M. A., Beljaars, A. C. M., Berg, L. V. D., Bidlot, J., Bormann, N., Caires, S., Chevallier, F., Dethof, A., Dragosavac, M., Fisher, M., Fuentes, M., Hagemann, S., Holm, E., Hoskins, B. J., Isaksen, L., Janssen, P. A. E. M., Jenne, R., McNally, A. P., Mahfouf, J.-F., Morcrette, J.-J., Rayner, N. A., Saunders, R. W., Simon, P., Sterl, A., Trenberth, K. E., Untch, A., Vasiljevic, D., Viterbo, P., and Woollen, J.: The COSMIC/FORMOSAT-3 mission: Early results, B. AM. Meteorol. Soc., 89, 313-333, 2008.

Brewer, A. W.: Evidence for a world circulation provided by the measurements of helium and water vapor distribution in the stratosphere, Q. J. Roy. Meteor. Soc., 75, 351-363, 1949.

Chae, J. H., Wu, D. L., Read, W. G., and Sherwood, S. C.: The role of tropical deep convective clouds on temperature, water vapor, and dehydration in the tropical tropopause layer (TTL), Atmos. Chem. Phys., 11, 3811-3821, doi:10.5194/acp-11-38112011, 2011.

Fierro, A. O., Simpson, J., LeMone, M. A., Straka, J. M., and Smull, B. F.: On how hot towers fuel the Hadley cell: An observational and modeling study of line-organized convection in the equatorial trough from TOGA COARE, J. Atmos. Sci., 66, 2730-2746, 2009.
Folkins, I. and Martin, R. V.: The vertical structure of tropical convection and its impact on the budgets of water vapor and ozone, J. Atmos. Sci., 62, 1560-1573, 2005.

Folkins, I., Loewenstein, M., Podolske, J., Oltmans, S. J., and Proffitt, M.: A barrier to vertical mixing at $14 \mathrm{~km}$ in the tropics: Evidence from ozonesondes and aircraft measurements, J. Geophys. Res., D18, 22095-22102, 1999.

Folkins, I., Braun, C., Thompson, A. M., and White, J.: Tropical ozone as indicator of deep convection, J. Geophys. Res., 107, 4184, doi:10.1029/2001JD001178, 2002.

Folkins, I., Fueglistaler, S., Lesins, G., and Mitovski, T.: A LowLevel Circulation in the Tropics, J. Atmos. Sci., 65, 1019-1034, 2008.

Fueglistaler, S., Bonazzola, M., Haynes, P. H., and Peter, T.: Stratospheric water vapor predicted from Lagrangian temperature history of air entering the stratosphere in the tropics, J. Geophys. Res., 110, D08107, doi:10.1029/2004JD005516, 2005.

Fueglistaler, S., Dessler, A. E., Dunkerton, T. J., Folkins, I., Fu, Q., and Mote, P. W.: Tropical tropopause layer, Rev. Geophys., 47, RG1004, doi:10.1029/2008RG000267, 2009.

Gettelman, A. and Birner, T.: Insights into Tropical Tropopause Layer processes using global models, J. Geophys. Res., 112, D23104, doi:10.1029/2007JD008945, 2007.

Gettelman, A. and Forster, P. M. d. F.: A climatology of the tropical tropopause layer, J. Meteor. Soc. Jpn., 80, 911-924, 2002.

Holloway, C. E. and Neelin, J. D.: The convective cold top and quasi equilibrium, J. Atmos. Sci., 64, 1467-1487, 2007.

Holton, J. R. and Gettelman, A.: Horizontal transport and the dehydration of the stratosphere, Geophys. Res. Lett., 28, 2799-2802, 2001.

Johnson, R. H. and Kriete, D. C.: Thermodynamic and circulation characteristics of winter monsoon tropical mesoscale convection, Mon. Weather Rev., 110, 1898-1911, 1982.

Kiladis, G. N., Straub, K. H., Reid, G. C., and Gage, K. S.: Aspects of interannual and intraseasonal variability of the tropopause and lower stratosphere, Q. J. Roy. Meteor. Soc., 127, 1961-1983, 2001.

Kiladis, G. N., Straub, K. H., and Haertel, P. T.: Zonal and vertical structure of the Madden-Julian oscillation, J. Atmos. Sci., 62, 2790-2809, 2005

Kiladis, G. N., Wheeler, M. C., Haertel, P. T., Straub, K. H., and Roundy, P. E.: Convectively coupled equatorial waves, Rev. Geophys., 47, RG2003, doi:10.1029/2008RG000266, 2009.

Kim, J. and Son, S.-W.: Tropical Cold-Point Tropopause: Climatology, Seasonal Cycle, and Intraseasonal Variability Derived from COSMIC GPS Radio Occultation Measurements, J. Climate, 25, 5343-5360, 2012.

Kley, D., Crutzen, P. J., Smit, H. G. J., Vömel, H., Oltmans, S. J., Grassl, H., and Ramanathan, V.: Observations of Near-Zero Ozone Concentrations over the Convective Pacific: Effects on Air Chemistry, Science, 274, 230-233, 1996.

Komhyr, W. D., Barnes, R., Brothers, G., Lathrop, J., and Opperman, D.: Electrochemical concentration cell ozonesonde performance evaluation during STOIC 1989, J. Geophys. Res., 100, 9231-9244, 1995.

Kursinski, E. R., Hajj, G. A., Bertiger, W. I., Leroy, S. S., Meehan, T. K., Romans, L. J., Schofield, J. T., McCleese, D. J., Melbourne, W. G., Thornton, C. L., Yunck, T. P., Eyre, J. R., and Nagatani, R. N.: Initial results of radio occultation observations 
of the Earth's atmosphere using the Global Positioning System, Science, 271, 1107-1110, 1996.

Kursinski, E. R., Haij, G. A., Schofield, J. T., Linfield, R. P., and Hardy, K. R.: Observing the Earth's atmosphere with radio occultation measurements using the Global Positioning System, J. Geophys. Res., 102, 23429-23465, 1997.

Liu, C. and Zipser, E. J.: Global distribution of convection penetrating the tropical tropopause, J. Geophys. Res., 110, D23104, doi:10.1029/2005JD006063, 2005.

Ma, D. and Kuang, Z.: Modulation of radiative heating by the Madden Julian Oscillation and convectively coupled Kelvin waves as observed by CloudSat, Geophys. Res. Lett., 38, L21813, doi:10.1029/2011GL049734, 2011.

Mitovski, T., Folkins, I., von Salzen, K., and Sigmond, M.: Temperature, Relative Humidity, and Divergence Response to High Rainfall Events in the Tropics: Observations and Models, J. Climate, 23, 3613-3625, 2010.

Mote, P. W., Rosenlof, K. H., McIntyre, M. E., Carr, E. S., Gille, J. G., Holton, J. R., Kinnersley, J. S., Pumphrey, H. C., Russell, J. M., I., and Waters, J. W.: An atmospheric tape recorder: The imprint of tropical tropopause temperatures on stratospheric water vapor, J. Geophys. Res., 101, 3989-4006, 1996.

Norton, W. A.: Tropical Wave Driving of the Annual Cycle in Tropical Tropopause Temperatures. Part II: Model Results, J. Atmos. Sci., 63, 1420-1431, 2006.

Paulik, L. C.: Quantifying deep convective influence on the tropical tropopause layer (TTL), Master's thesis, Department of Atmospheric Science, Colorado State University, 122 pp., 2011.

Randel, W. J. and Thompson, A. M.: Interannual variability and trends in tropical ozone derived from SAGE II satellite data and SHADOZ ozonesondes, J. Geophys. Res., 116, D07303, doi:10.1029/2010JD015195, 2011.

Randel, W. J. and Wu, F.: Thermal variability of the tropical tropopause region derived from GPS/MET observations, J. Geophys. Res., 108, 4024, doi:10.1029/2002JD002595, 2003.

Romps, D. M. and Kuang, Z.: Do Undiluted Convective Plumes Exist in the Upper Tropical Troposphere?, J. Atmos. Sci., 67, 468-484, 2010.

Sassen, K. and Wang, Z.: Classifying clouds around the globe with CloudSat radar: 1-year of results, Geophys. Res. Lett., 35, L04805, doi:10.1029/2007GL032591, 2008.

Sherwood, S. C. and Wahrlich, R.: Observed Evolution of Tropical Deep Convective Events and Their Environment, Mon. Weather Rev., 127, 1777-1795, 1999.
Sherwood, S. C., Horinouchi, T., and Zeleznik, H.: Convective impact on temperatures observed near the tropical tropopause, J. Atmos. Sci., 60, 1847-1856, 2003.

Solomon, S., Portmann, R. W., Sasaki, T., Hofmann, D. J., and Thompson, D. W. J.: Four decades of ozonesonde measurements over Antarctica, J. Geophys. Res., 110, D21311, doi:10.1029/2005JD005917, 2005.

Stephens, G. L., Vane, D. G., Boain, R. J., Mace, G. G., Sassen, K., Wang, Z., Illingworth, A. J., O'Connor, E. J., Rossow, W. B., Durden, S. L., Miller, S. D., Austin, R. T., Benedetti, A., Mitrescu, C., and The CloudSat Science Team: The CloudSat Mission and the A-Train, B. Am. Meteorol. Soc., 83, 1771-1790, 2002.

Takahashi, H. and Luo, Z.: Where is the level of neutral buoyancy for deep convection?, Geophys. Res. Lett., 39, L15809, doi:10.1029/2012GL052638, 2012.

Thompson, A. M., Witte, J. C., McPeters, R. D., Oltmans, S. J., Schmidlin, F. J., Logan, J. A., Fujiwara, M., Kirchhoff, V. W. J. H., Posny, F., Coetzee, G. J. R., Hoegger, B., Kawakami, S., Ogawa, T., Johnson, B. J., Vomel, H., and Labow, G.: Southern Hemisphere Additional Ozonesondes (SHADOZ) 1998-2000 tropical ozone climatology 1. Comparison with Total Ozone Mapping Spectrometer (TOMS) and ground-based measurements, J. Geophys. Res., 108, 8238, doi:10.1029/2001JD000967, 2003a.

Thompson, A. M., Witte, J. C., Oltmans, S. J., Schmidlin, F. J., Logan, J. A., Fujiwara, M., Kirchhoff, V. W. J. H., Posny, F., Coetzee, G. J. R., Hoegger, B., Kawakami, S., Ogawa, T., Fortuin, J. P. F., and Kelder, H. M.: Southern Hemisphere Additional Ozonesondes (SHADOZ) 1998-2000 tropical ozone climatology 2. Tropospheric variability and the zonal wave-one, J. Geophys. Res., 108, 8241, doi:10.1029/2002JD002241, 2003b.

Thompson, A. M., Allen, A. L., Lee, S., Miller, S. K., and Witte, J. C.: Gravity and Rossby wave signatures in the tropical troposphere and lower stratosphere based on Southern Hemisphere Additional Ozonesondes (SHADOZ), J. Geophys. Res., 116, D05302, doi:10.1029/2009JD013429, 2011.

Zeng, Z., Ho, S.-P., Sokolovskiy, S., and Kuo, Y.-H.: Structural evolution of the Madden-Julian Oscillation from COSMIC radio occultation data, J. Geophys. Res., 117, D22108, doi:10.1029/2012JD017685, 2012. 